
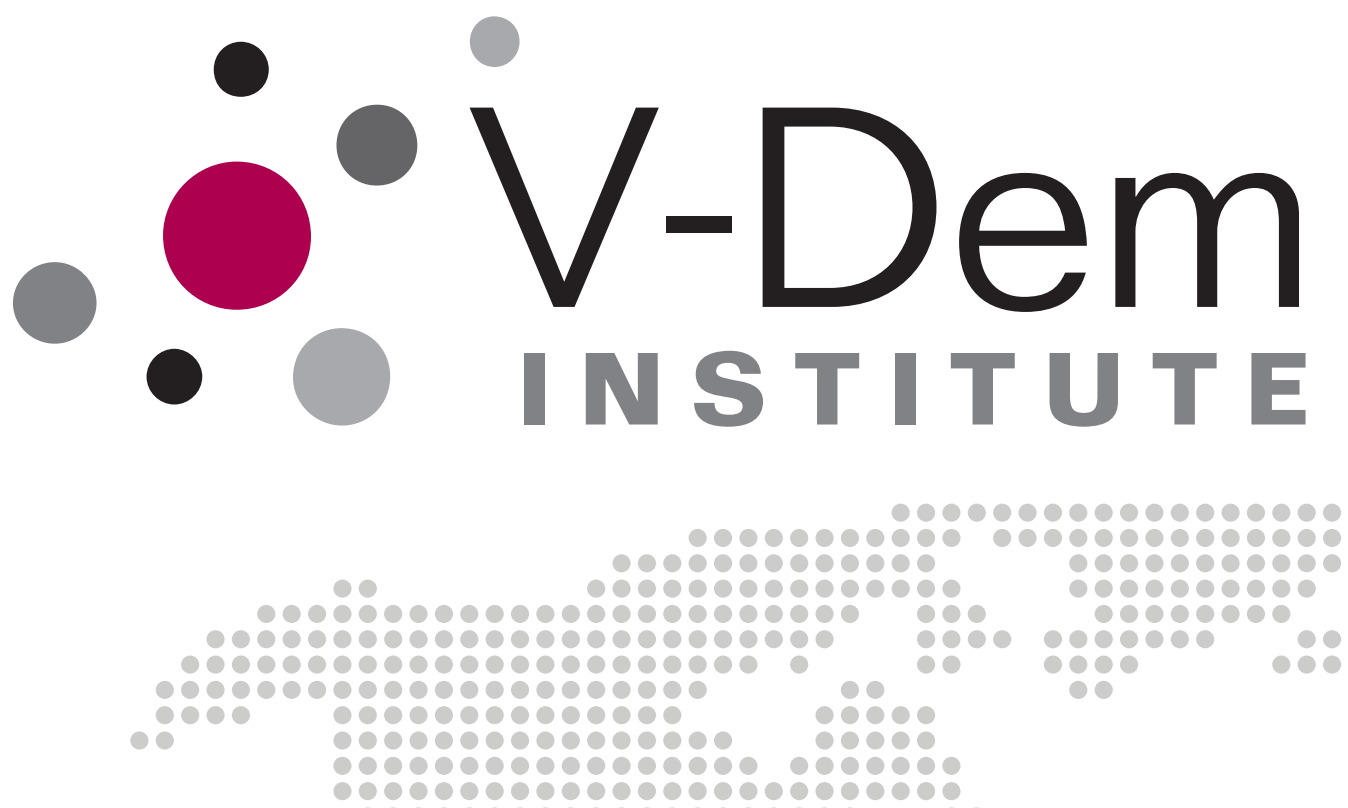$$
10090
$$
00000
ren

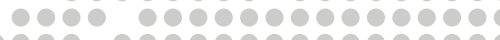 1000

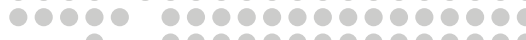 10 20000000000000

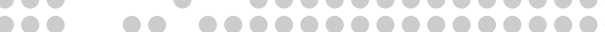

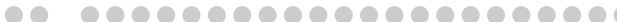
190

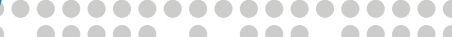

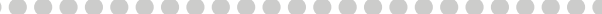

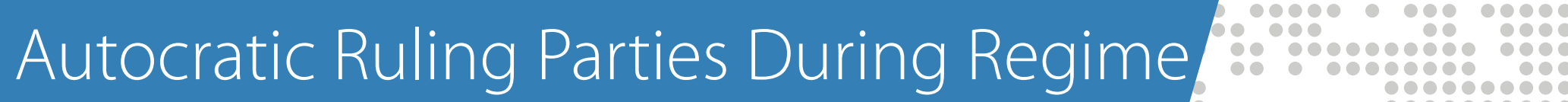

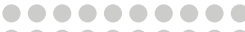
000090000 Transitions: Investigating the Democratizing Effect of Strong Ruling 1000 10 00000000000000

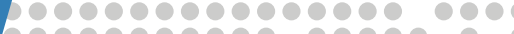

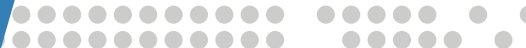

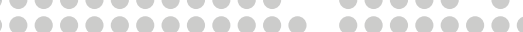

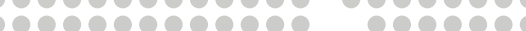

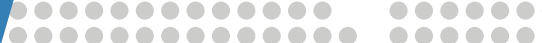
Parties

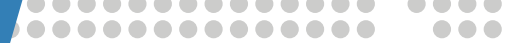

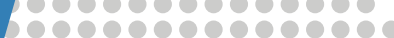

P0000000000000000000 100000000000000000000 10000000000000000

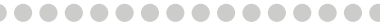
90000000000000 000000000000 00000000000 0000000000 -

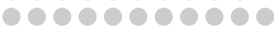

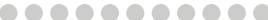
00000000000

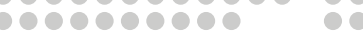

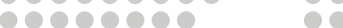
00000000000 1000000

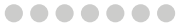
00000 1000 00000000 1000000 000000 000000 10000 000 000 10 00 90 
Varieties of Democracy ( $\mathbf{V}-$ Dem) is a new approach to conceptualization and measurement of democracy. The headquarters - the V-Dem Institute - is based at the University of Gothenburg. The project includes a worldwide team with five Principal Investigators, 18 Project Managers, 30 Regional Managers, 170 Country Coordinators, Research Assistants, and 3,000 Country Experts. The V-Dem project is one of the largest ever social science research-oriented data collection programs.

Please address comments and/or queries for information to:

$\mathrm{V}$-Dem Institute

Department of Political Science

University of Gothenburg

Sprängkullsgatan 19, PO Box 711

SE 40530 Gothenburg

Sweden

E-mail: contact@v-dem.net

$\mathrm{V}$-Dem Working Papers are available in electronic format at www.v-dem.net.

Copyright (C) 2020 by the authors. All rights reserved. 


\title{
Autocratic Ruling Parties During Regime Transitions: Investigating the Democratizing Effect of Strong Ruling Parties*
}

\author{
Yaman Berker Kavasoglu \\ University of Gothenburg
}

*This research project was supported by Vetenskapsrådet, Grant 439-2014-38, PI: Ellen Lust, University of Gotneburg, Sweden; by Knut and Alice Wallenberg Foundation to Wallenberg Academy Fellow PI: Staffan I. Lindberg, Grant 2018.0144, V-Dem Institute, University of Gothenburg, Sweden; by Vetenskapsrådet, Grant 2018-01614, PI: Anna Lührmann, V-Dem Institute, University of Gothenburg, Sweden. I thank Staffan I. Linberg, Anna Lührmann, Jonathan Polk, Pedro Riera, Jean Lachapelle, Amanda B. Edgell, Juraj Medzihorsky, and Stephen Dawson for comments and suggestions. 


\section{Abstract}

This study examines the role of autocratic ruling party strength in democratic transitions. While the impact of ruling party strength on regime stability is extensively studied, we know much less about when and why ruling party strength can facilitate democratization during regime transitions. Proceeding from recent studies that suggest autocratic incumbents often choose to democratize from a position of strength rather than weakness, I discuss how specific attributes strong ruling party organizations wield can provide autocratic incumbents with incentives and capabilities to lead democratization in the context of regime change. Using an original data on organizational characteristics of 161 autocratic ruling parties between 1970 and 2015, I provide the first set of systematic empirical evidence supporting the argument that ruling party organizational features that promote regime durability can simultaneously facilitate the implementation of substantial democratizing reforms by regime elites in a top-down fashion to preempt political opposition. 


\section{Introduction}

Extensive work argues that strong ruling party organizations promote autocratic regime durability by containing conflict among the members of the ruling coalition, co-opting opposition groups, and mobilizing the masses in support of the regime (Boix and Svolik 2013; Brownlee 2007; Geddes 1999; Geddes, Wright, and Frantz 2018; Greene 2007; Levitsky and Way 2010; Magaloni 2006; 2008; Magaloni and Kricheli 2010; Slater 2010; Smith 2005; Svolik 2012). Hence, there is a consensus in the literature that autocratic regimes that invest in ruling party organizations survive longer than those do not.

However, while regime stabilizing effects of ruling parties are extensively studied, we know much less about the role of ruling parties during regime transitions. Specifically, our understanding of how ruling party strength shapes transition outcomes comes mainly from qualitative work based on a limited number of cases (e.g. Riedl et al. 2020) or quantitative analyses that use proxy measures of party strength that are limited in their ability to capture key attributes of ruling party organizations (e.g. Brownlee 2009; Miller 2020; Wright and Escribà-Folch 2012).

In this study, proceeding from existing insights that suggest autocratic incumbents often choose to democratize from a position of strength rather than weakness (e.g. Albertus and Menaldo 2018; Riedl et al. 2020; Slater and Wong 2013; Ziblatt 2017), I contend that ruling party strength is both a regime-stabilizing force and a democratizing force. Although strong ruling parties generally stabilizes regimes, in the context of regime change they can function as catalysts for the implementation of substantial democratizing reforms by regime elites in a top-down fashion to preempt political opposition.

In particular, this study draws on recent explanations that suggest a ruling party's perceived capacity to influence the distribution of political power in a subsequent democracy lessen incumbents' imperative to sustain the autocratic rule given an increasing probability of a regime change (Riedl et al. 2020; Slater and Wong 2013; Wright and Escribà-Folch 2012; Ziblatt 2017). In this perspective, incumbents strategically implement liberalizing reforms to avoid relatively more costly pathways to regime change (see also Acemoglu and Robinson 2005), and when they can rely on a strong ruling party 
that can ensure their electoral dominance despite of increasingly democratic elections.

Although previous studies provide important insights, they overlook the mechanisms by which ruling parties ensure coordination and unity within the regime ranks when it comes to furthering liberalizing reforms. While incumbents' positive perceptions of the ruling party's ability to alleviate threats from outsider opposition groups might compel them to enact political reforms, the prospects for this strategy also depends on the party's capacity to facilitate coordination within the ruling coalition. Given that political liberalization can aggravate divisions among the regime elites, which can eventually hinder the transition process (O'Donnell and Schmitter 1986; Przeworski 1991), it is important to understand which sources of ruling party strength can facilitate elite coordination to implement liberalizing reforms. In this study, I relax the assumption that the regime elites hold homogeneous preferences toward democratization when the costs of sustaining the existing regime outweigh the costs associated with political reforms, and argue that the likelihood of regime elites implementing substantial democratizing reforms is a function of ruling parties' capacity to simultaneously solve challenges of elite and mass coordination during regime transitions.

Accordingly, I conceptualize ruling party strength in terms of three interrelated aspects of internal party characteristics: institutionalization, cohesion, and organizational extensiveness. Institutionalization - defined as the creation of rules and procedures that shape the distribution of power and resources among regime elites (Meng 2019), and cohesion are particularly important for eliciting elite coordination whereas organizational extensiveness corresponding to the parties' sub-national presence and affiliated social organizations are crucial for mass coordination. Together these features shape the regime elites' capabilities and incentives to lead democratization without spiraling into internal struggle or acquiescing to outsider opposition groups.

In empirical analyses, using novel party-specific indicators of organizational characteristics of 161 autocratic ruling parties from 1970 to 2015, I develop a new measure of party strength that captures the degree to which a ruling party exhibits aforementioned three conceptual attributes over time. The measure draws on new indicators that are collected 
at the party-level (Lührmann et al. forthcoming) and coded by Varieties of Democracy (Coppedge et al. 2020) country experts. This study presents the first systematic examination of how time-varying autocratic ruling party organizational attributes shape prospects for democratization. The results corroborate the expectation that ruling party strength generally stabilizes autocratic regimes but increase the likelihood of democratization led by incumbents given a regime change. I find robust evidence that strong ruling parties facilitate the implementation of democratizing reforms by incumbents in the context of regime change.

In the sections that follow I first provide an overview of the debate on autocratic ruling parties and regime outcomes. This is followed by the conceptualization of ruling party strength, and the discussion of theoretical mechanisms linking party organizational attributes to a regime's propensity to experience a regime change in the form of democratization led by incumbent elites. I then present empirical tests that simultaneously estimate regime-strengthening and democratizing effects of ruling parties.

\section{Background}

A large literature examines the role of ruling parties in maintaining autocratic regime stability (Boix and Svolik 2013; Brownlee 2007; Geddes 1999; Geddes, Wright, and Frantz 2018; Levitsky and Way 2010; Magaloni 2008; Miller 2020; Smith 2005; Slater 2010; Svolik 2012; Wright and Escribà-Folch 2012). Specifically, studies suggest that ruling parties provide institutional mechanisms that contain elite conflict, ensuring regime cohesiveness crucial for autocratic stability (Boix and Svolik 2013; Brownlee 2007; Magaloni 2008; Reuter 2017; Svolik 2012). Moreover, ruling party organizations also distribute patronage to elites and social groups, monitor compliance, and mobilize the masses in support of the regime (Blaydes 2010; Geddes, Wright, and Frantz 2018; Greene 2007; Levitsky and Way 2010; Magaloni 2006; Magaloni and Kricheli 2010; Malesky and Schuler 2010; Slater 2010).

Beyond promoting autocratic survival, several studies suggest that ruling parties may 
paradoxically promote democratization (Riedl et al. 2020; Slater and Wong 2013; Wright and Escribà-Folch 2012; Ziblatt 2017). In particular, these studies hold that strong ruling parties empower regime elites to make democratic concessions to political opposition without risking their survival in the office. Accordingly, when the costs of pursuing political liberalization are lower than the costs of not doing so, regime elites have incentives to implement liberalizing reforms. Most recently, Riedl et al. (2020) argue that ruling party strength is "the permissive condition" that compels regime elites to enact liberalizing reforms in the face of growing pressures for political liberalization. Central to their argument is the ruling party's perceived ability to thwart electoral challenges and maintain its dominance despite of increasingly democratic elections. Similarly, Wright and Escribà-Folch (2012) contend that dominant parties' capacity to mobilize votes ensures that regime elites can continue to influence the distribution of power in a democracy, which reduces regime elites' incentives to cling onto autocracy during regime transitions. Indeed, many ruling parties have remained in power despite transitioning to democracy (Miller 2019). Some concede electoral defeats and transform into highly competitive opposition as authoritarian successor parties, typically coming back to power in subsequent rounds of democratic elections (Grzymala-Busse 2020). Examples include National Democratic Congress (Ghana), Colorado Party (Paraguay), Hungarian Socialist Workers' Party (Hungary), among others.

This study is deeply grounded in this body of research, but it seeks to improve several important shortcomings in our understanding of when and why ruling party strength can facilitate democratization. First, existing studies implicitly assume that regime elites hold homogeneous preference toward political liberalization during regime transitions. Consequently, the arguments primarily rest on the regime elites' incentives to pursue political reforms as a function of the ruling party's capacity to thwart outsider challengers. As a result, it remains unclear how ruling parties enable regime elites to coordinate among themselves to lead liberalizing reforms. Given that various factions within the regime may see liberalization as threatening to their interests and consequently attempt to disrupt the process by removing the incumbent (O’Donnell and Schmitter 1986; Przeworski 
1991), it is important to understand how ruling parties reduce internal obstacles to leading political liberalization. While external challenges can influence elite incentives to coordinate, how regime elites respond to such challenges is to a great extent a function of internal party characteristics that structure elite behavior. In the following sections, I address the challenges of elite coordination by expanding the concept of ruling party strength to include elite-level institutionalization (see Meng 2019). My argument complements existing explanations by highlighting the sources of ruling party strength that enable regime elites to lead liberalization without spiraling into internal struggle, while competing against political opposition.

Second, I push the literature forward by providing the first rigorous systematic examination of the association between ruling party strength and democratization. Although Wright and Escribà-Folch (2012) present Large-N statistical analysis, they attempt to provide evidence by using regime types as a proxy for ruling party strength. Nevertheless, the evidence suggests that regime typologies perform poorly in capturing the strength of ruling parties (Meng 2019). In addition, Wright and Escribà-Folch (2012) do not distinguish between regime transitions that have occurred due to political reforms implemented by incumbents and those that have followed from other types of processes such as coups or mass uprisings in which the event of regime change results from the forced ouster of incumbents. In this study, I address these shortcomings by providing empirical tests using a new time-varying measure of ruling party strength based on party-specific indicators. Moreover, I provide more direct examination of the existing arguments by systematically distinguishing between incumbent-led democratic transitions and other forms of regime change. 


\section{Theoretical Framework}

\section{Conceptualizing Autocratic Ruling Party Strength:}

\section{Institutionalization, Cohesion, and Organizational Extensiveness}

I contend that strong ruling parties are those that develop a stable and formalized set of rules that guide the distribution of power among regime elites together with entrenched linkages to constituencies. Specifically, ruling party strength can be assessed in terms of three interrelated aspects of internal party characteristics. One crucial feature of strong ruling parties is elite-level institutionalization, which can be defined as the process by which decision-making structures increasingly follow a clear set of formalized rules and procedures (Meng 2019). In highly institutionalized ruling parties, decisions are taken in accordance with established guidelines that regularize how power and resources are distributed among regime elites. The regularization of such processes raises the costs of deviating from established rules and constrains actor behavior, resulting in what Levitsky (1998) refers to as "behavioral routinization". Institutionalization is especially important in autocracies because it prevents the predation of the party organization by constraining autocratic leaders (Meng 2019). In ruling party organizations where elitelevel institutionalization is low, the distribution of power and resources among regime elites typically follow unclear rules and procedures that often depend on temporary arrangements based on informal personalized networks. Under such circumstances, ruling parties rarely serve as inter-temporal commitment tools that enable elites to establish lasting credible power-sharing deals critical for organizational durability (Meng 2019).

Another feature that contributes to ruling party strength is a high level of elite cohesion, which is related but distinct from institutionalization. Cohesion refers to the ability of a ruling party to ensure cooperation among regime elites (Levitsky and Way 2010). Where cohesion is low ruling parties' ability to rule is significantly reduced and regimes are prone to elite defections. All else equal, cohesion should be higher in ruling parties with a high degree of institutionalization, but sources of cohesion can vary. Levitsky and Way (2012), for instance, argue that norms and identities generated during 
periods of sustained, ideologically-driven violent conflict provide ruling parties with a robust source of cohesion. Nevertheless, ruling parties can be highly cohesive due to the personal charisma of the leader or primarily because of the continuous flow of patronage. Irrespective of its sources, however, elite cohesion is critical for the prevention of elite defections, and ultimately for the strength of ruling parties.

Finally, organizational extensiveness is another feature that contributes to ruling party strength. Organizationally extensive parties are those that have considerable sub-national presence and affiliated mass-mobilizing structures that support party operations with material resources and personnel. Absent these qualities, ruling parties rarely develop into enduring organizations (Morse 2018).

How much ruling parties incorporate these attributes is a matter of degree, which varies over time and across parties. Three components are interrelated and at times they can reinforce each other. While a party's weakness in one attribute can be partly compensated by its strength in another, the strongest ruling parties are ideally those that are highly institutionalized, cohesive and organizationally extensive. In the next section, I discuss how the qualities strong ruling parties wield can enable them to simultaneously solve challenges of elite and mass coordination crucial for implementing democratizing reforms.

\section{Incentives and Capabilities to Lead Democratization}

Regime elites initiate and guide democratization not necessarily because they have normative preference for democracy. Previous research suggests that regime elites often implement democratizing reforms as preemptive measures to avoid more costly pathways to regime change or when they consider democracy to serve their interests better than autocracy (Acemoglu and Robinson 2005; Albertus and Gay 2018; Albertus and Menaldo 2018; Boix 2003). The existing evidence demonstrates that when autocratic incumbents accede to democracy, they generally face better post-tenure fates than they would if they were to resist democratization or replaced by rival autocrats (Debs 2016; Geddes, Wright and Frantz 2014; Geddes, Wright, and Frantz 2018; Wright and Escribà-Folch 2012). 
Importantly, regime elites can safeguard their interests in a subsequent democracy by negotiating an extrication or by erecting constitutional rules that preserve their privileges in the long-term (Albertus and Menaldo 2018; Riedl 2014). Further, transitions to democracy do not necessarily result in ruling parties' loss of power. Miller (2020) counts that in two-thirds of democratic transitions between 1940 and 2010, ruling parties have managed to stay in power. In these cases, ruling parties can even gain some benefits from democratization by expanding their social base and potentially attracting external financial resources (Riedl et al. 2020). However, when incumbents resist democratization in spite of poor prospects for regime survival, the modal outcome is transition to a new autocratic regime in which bargaining for a transition on favorable terms is unlikely, and the odds of punishment for outgoing elites are high (Debs 2016; Geddes, Wright and Frantz 2014; Geddes, Wright, and Frantz 2018; Wright and Escribà-Folch 2012). Hence, while preserving the status quo is the optimal outcome for regime elites, the literature provides important reasons for them to implement democratizing reforms when the costs of doing so is conceived to be lower than the costs associated with suppressing demands for reforms.

Transition trajectories are shaped by struggles between incumbents aiming to remain in power, political opposition attempting to oust incumbents, and regime elites seeking to prevent outcomes that can threaten their interests (Bernhard, Edgell and Lindberg 2020; O’Donnell and Schmitter 1986; Przeworski 1991). Hence, in leading democratizing reforms incumbents are challenged not only by political opposition, but also by factions within the ruling coalition. As such, ruling parties should have the necessary sources of strength to simultaneously overcome challenges of coordinating regime elites while competing against outsider opposition groups.

Strong ruling parties enhance incumbents' capability to reinforce coordination among the key factions within the regime in at least three ways. First, an important attribute of strong party organizations is a high level of elite-level institutionalization, which entails the creation of formalized and reqularized rules of engagement and decision-making procedures (Meng 2019). Such organizational features provide institutionalized mech- 
anisms through which incumbents can bargain and agree on comprehensive deals with those that can potentially disrupt the process from within. Decision-making procedures based on stable, clear and transparent rules allow incumbents to strike deals that can credibly signal to regime elites that their interests will be protected (Boix and Svolik 2013; Magaloni 2008; Svolik 2012).

Second, strong party organizations provide institutional tools for monitoring internal regime factions' compliance with the terms of liberalizing reforms as the regime transition unfolds. Institutionalization involves the development of hierarchical positions and procedures that formalize the distribution of power and resources among regime elites (Meng 2019). The hierarchical nature of ruling party organizations enables top cadres to monitor and exert control over individual party members (Malesky and Schuler 2010). Haggard and Kaufman (1995), for instance, show how ruling parties with centralized decisionmaking structures - such as Kuomintang (Taiwan) and Institutional Revolutionary Party (Mexico) - have successfully managed gradual implementation of liberalizing reforms by facilitating legislative coordination. Such qualities help ensure that political reforms are implemented as agreed. Moreover, institutionalization encompasses the creation of organizational structures that promote collegial leadership where regime elites can oversee the actions of incumbents (Boix and Svolik 2013; Svolik 2012). Institutionalized parties hold regular party congresses and executive committee meetings, and operate under established rules that limit the tenure of leaders. Such procedures prevent predation by autocratic incumbents and create incentives to respond to interests of regime elites. Strong ruling parties therefore provide credible checks on executive power as well as on individual party members, which should facilitate internal regime coordination fundamental to managing liberalizing reforms.

Third, the high levels of elite cohesion that strong parties wield make them wellpositioned to remain unified in challenging contexts such as regime transitions. While ruling parties generally give the impression of cohesiveness in normal times, when regimes are threatened by economic crisis, rising opposition challenges, or withdrawal of external support many suffer from elite defections that undermine their survival (Levitsky 
and Way 2012; Reuter and Gandhi 2011; Reuter and Szakonyi 2019). Regime transitions represent one of those challenging moments that can encourage defections of key regime elites (Geddes, Wright, and Frantz 2018). Elite defections can significantly hinder the incumbents' ability to control the transition process in several ways. First, when a prominent elite defects to opposition it signals ruling party weakness that can encourage further defections in lower cadres. Second, the defection of prominent elites can encourage opposition groups to overcome collective action problems that can consequently lead to the formation of electorally powerful broad opposition coalitions (Van de Walle 2006). Third, defectors can simply overthrow the government by unconstitutional means. While even the strongest ruling parties may occasionally experience elite defections, defectors rarely attract enough followers from grassroots organizations. In these cases, defections often remain as isolated events that do not cause much damage to ruling parties (Geddes, Wright, and Frantz 2018; Levitsky and Way 2010).

Absent organizational qualities that ensure elite coordination, ruling parties generally lack the capacity to successfully implement necessary political reforms to lead the transition process. In the context of ruling party weakness, regime transitions are likely to be hampered by struggles between rival internal regime factions, which can exacerbate ruling parties' vulnerability to pressures from political opposition. The Zambian and Beninese transitions in the early 1990s exemplifies this scenario. In both cases, incumbents initiated political reforms hoping to entrench their hold on power, yet they subsequently yielded to the political opposition largely because of their inability to ensure coordination within the regime ranks (Gisselquist 2008; Riedl 2014).

In addition, strong ruling parties facilitate mass coordination which further bolster incumbents' ability to contain pressures from opposition groups outside the regime ranks. Strong ruling parties' countrywide presence help incumbents establish longstanding ties to the masses through which they can effectively mobilize support (Levitsky and Way 2010; Morse 2018; Riedl et al. 2020). Such qualities strong party organizations wield become especially important as incumbents lift barriers for opposition parties and allow for increasingly competitive elections. The ability to withstand pressures from opposi- 
tion parties during regime transitions often enables incumbents to maintain legislative majorities crucial for implementing democratizing reforms. Even when ruling parties has to eventually step down in subsequent periods of the transition process, their ability to remain as electorally competitive enables them to transform themselves into effective opposition parties that can prevent incoming governments from reverting back to authoritarianism (Grzymala-Busse 2020). As Riedl et al. (2020) demonstrate, such sources of strength are crucial to compel incumbents to enact democratizing reforms in the first place. When these qualities are coupled with ruling parties' competence in maintaining elite coordination, incumbents are less likely to miscalculate their chances of implementing democratizing reforms while protecting their interests.

In sum, the argument presented here implies that strong ruling parties create incentives and capabilities for incumbents to concede to demands for democratizing reforms when the costs of sustaining the status quo surpass the costs of implementing political reforms. ${ }^{1}$ Taken these considerations together, in the empirical analysis I test the following hypothesis: Greater ruling party strength increases the likelihood of incumbent-led democratization (conditional on regime change).

\section{Research Design}

\section{Sample and Dependent Variable}

I examine the relationship between party strength and incumbent-led democratization on a sample of 161 autocratic ruling parties between 1970 and 2015, subject to data availability. The unit of analysis is the country-year. Autocracies are identified using data from Boix, Miller and Rosato (2013). The empirical analysis is limited to autocracies with ruling parties, given that the aim is to explain how variation in party strength influences regimes' propensity to experience regime change in the form of democratization led by incumbents. The data set covers ruling parties that are either the supreme ruling power or used as an important vehicle for power by the regime (Miller 2020).

To construct the dependent variable, I proceed in two steps. First, using data from 
Miller (2019), I identify regime changes which involve the ruling party's loss of power to a new autocracy (i.e. a transfer of power to a new autocratic ruling party or a non-party autocracy) and democratization (as indicated in Boix, Miller and Rosato (2013)). Second, I use data from Djuve, Knutsen and Wig (2020) to identify democratic transitions that have preceded by substantial democratizing reforms initiated and implemented mainly by incumbents (i.e. incumbent-led democratization). The estimation sample includes a total of 98 regime changes of which 31 are incumbent-led democratic transitions. The remaining 67 regime changes correspond to transitions enforced by dissidents within the regime or opposition groups outside the regime ranks (i.e. military coups, mass protests, civil war, foreign interventions, substantial democratization resulting from an unexpected election loss).

\section{Independent Variable: Measuring Ruling Party Strength}

This study introduces a new measure of ruling party strength based on unique indicators from V-Party Project (Lührmann et al. forthcoming). Although parties feature prominently in many studies of authoritarianism, there have been no data on internal organizational characteristics of ruling parties measured at the party-level. Consequently, previous studies attempt to measure party strength using indicators such as regime types (Wright and Escribà-Folch 2012), party origins (Geddes, Wright, and Frantz 2018; Miller 2020), or party age (Gehlbach and Keefer 2011) which are often poor proxies for conceptual attributes scholars aim to capture. This study fills this shortcoming by presenting the first time-varying measure of ruling party strength based on novel indicators that are collected at the party-level.

As discussed, strong ruling parties are defined as those that are institutionalized, cohesive, and organizationally extensive. Meng (2019) argues that an important feature of institutionalized parties is the presence of rules and procedures that guarantee the organization's autonomous existence from the individual leader. Accordingly, institutionalization entails the formalization of distribution of power within the party that de-personalizes the ways in which the party organization operates. This builds on the 
works of Huntington (1968) and Panebianco (1988) who suggest institutionalized parties are ones that have the ability to operate independently of individual leaders. Following this line of reasoning, the first indicator captures the extent to which a ruling party operates as an instrument of a leader to further her individual ambitions rather than representing the interests of a broader party organization. The second indicator measures internal party cohesiveness. This variable captures the degree to which party members display unity over fundamental party strategies, where lower scores indicates less internal cohesion.

As for organizational extensiveness, I consider three indicators. The first indicator corresponds to local party branches, which denotes whether a party maintains permanent branches at the local/municipal level across the country. An increase on this indicator represents a party's penetration into new municipalities by establishing permanent party branches. The second indicator focuses on the scope of a party's local reach by measuring the degree to which party activists and personnel are active in local communities. Specifically, this variable aims to capture a party's reach beyond formal branches in establishing stable linkages to constituencies. Finally, the third indicator measures the strength of a party's ties to prominent social organizations (i.e. labor unions, business organizations, religious organizations etc.). The ties are stronger when a party controls prominent social organizations that contribute to its operations by providing material and personnel resources, as well as by helping a party in propagating its message to organizations' members and beyond.

A ruling party organization's degree of institutionalization and cohesion primarily map on to mechanisms that bolsters incumbents' ability to elicit elite coordination, whereas organizational extensiveness involving a party's subnational presence and affiliated social organizations are especially important for incumbents' capacity to facilitate mass coordination.

All five indicators are based on the V-Party expert survey (Lührmann et al. forthcoming). Section 1 in the appendix provides exact wording, clarifications and response categories for each survey questions presented to thousands of country experts around 
the world. All experts are recruited based on their expertise on political parties in each country. Once expert responses are collected, a custom-made Bayesian item response model is used to convert expert responses from ordinal scores into interval scores that capture values of the observed latent phenomenon (Pemstein et al. 2020). The five indicators are standardized and averaged together to construct a ruling party strength index. In line with my conceptualization, this allows for partial substitutability between the index's components in that low scores in one component can be partly compensated by high scores on the other but high scores in all components indicate a stronger ruling party.

The appendix presents examinations of the index's validity. Figure 1 of section 1 in the appendix presents a histogram of ruling party strength for all 161 ruling parties across 2286 country-year observations that study's estimation sample covers. The measure varies from -3.09 to 2.37 , with a mean of 0 . When examined over time, there is a significant drop in ruling party strength across autocracies from late 1980s to mid 1990s (a period corresponding to the collapse of Communsit one-party regimes in Central and Eastern Europe and the introduction of multiparty elections in many African countries). Figure 3 in the appendix illustrates overtime changes in the strength of selected ruling parties (Communist Party of China, Institutional Revolutionary Party in Mexico, United National Independence Party in Zambia). The strength of these ruling parties vary overtime in accordance with expectations. In terms of convergent validity, the measure is positively correlated with party age $(r=0.32)$. When compared to regime type measures as presented in Geddes, Wright and Frantz (2014), ruling party strength is significantly higher in party-based regimes than military and personalist regimes. Nevertheless, the measure also highlights significant within regime type variation in ruling party strength, which would go unnoticed with discrete regime type indicators. Importantly, not all party-based regimes have strong ruling parties, which is in line with Meng 's (2019) critique of the use of regime type measures as a proxy for party strength. Similarly, not all ruling parties in personalist regimes are uniformly weak. These assessments illustrate the utility of the new measure of ruling party strength. 


\section{Control Variables}

I control for several potential confounding variables. First, economic conditions might affect both ruling party strength and regime changes. As modernization theory suggests, economic development might spur greater domestic pressures for regime change (Boix and Stokes 2003). Alternatively, economic development can stabilize autocratic regimes by bolstering state strength and increasing incumbents' ability to co-opt opposition groups (Miller 2012). Moreover, short-term economic growth can significantly impact regime stability by influencing ruling party strength and regime support among the population (Levitsky and Way 2010). I measure economic development as the natural log of real gross domestic product (GDP) per capita and economic growth as the annual changes in GDP (Boilt et al. 2018).

Rents from natural resources can also be used to stabilize regimes. Natural resource income can help fund ruling party organizations or it can lessen autocrats' need for investing in party organizations as a survival strategy. Accordingly, I control for the natural $\log$ of a country's oil production per capita (Ross and Mahdavi 2015).

Additionally, I control for the international context. Studies show that democratization tends to diffuse across national borders (Houle, Kayser and Xiang 2016). Moreover, the Cold War era provided more leeway for autocrats, which generally decreased the likelihood of democratization compared to the post-Cold war era (Levitsky and Way 2010). The international context can also impact ruling parties by shaping the availability of financial resources from international donors that can be used to fund party organizations. I control for the international context with a measure of the proportion of democratic regimes as recorded in Boix, Miller and Rosato (2013) in a country's region, and by including a dummy variable for the Cold War period (pre-1990).

Recent studies suggest ruling parties' founding origins influence their organizational strength and durability (Levitsky and Way 2012; Miller 2020). Specifically, Levitsky and Way (2012) argue that ruling parties with origins in revolutionary movements tend to be especially stronger than other ruling parties. Using time-series cross-sectional data, Miller (2020) finds that revolutionary and communist parties (organized as communist 
with foreign involvement) are significantly more durable than parties with other founding origins. In addition to revolutionary and communist origins, I control for parties established by military regimes, which tend to be weaker than other ruling parties and more likely to experience a transition to democracy (Geddes, Wright, and Frantz 2018). I control for ruling parties' founding origins by using data from Miller (2020). Finally, I control for party age.

\section{Empirical Model}

This study examines the relationship between autocratic ruling party strength and the likelihood of incumbent-led democratization. To empirically model this relationship, I estimate Heckman (1979) selection models in which the first stage (selection equation) models the likelihood of an autocracy experiences a regime change, and the second stage (outcome equation) estimates the likelihood that a regime change will be in the form of incumbent-led democratization. Given that unobserved factors such as strategic motivations of incumbents are likely to influence outcomes in both equations, the two equations must be considered simultaneously. Treating the two equations as independent can lead us to overlook the self-selective character of incumbent-led democratic transitions which is likely to result in either under or overestimation of the impact of ruling party strength or other covariates on the probability of incumbent-led democratic transitions. Heckman selection models account for such sources of bias. For the selection equation, I estimate a probit model in which the dependent variable is a dummy that indicates a regime change. In the outcome equation, I run a probit model where the estimated average response function of incumbent-led democratization is conditioned on the selection equation. Hence, the outcome equation estimates the likely pathway to a regime change for the cases in which a regime change has occured. ${ }^{2}$ In the outcome equation, the dependent variable is a dummy that indicates an event of incumbent-led democratization.

Selection models tend to work better when one can include an instrument that influences the selection outcome but not the outcome in the second stage equation. ${ }^{3}$ Accordingly, the selection equation additionally includes previous number of regime changes in 
a country's history as an instrument - calculated using data from Djuve, Knutsen and Wig (2020). I expect history of regime instability to be significantly associated with a higher likelihood of subsequent regime changes but have no influence on transition outcomes. The validity of this instrument depends on two criteria: (1) it should be relevant for predicting regime changes and (2) it should affect transition outcomes only through its effects on regime changes (no independent effect, i.e. exclusion restriction). Although there is no direct way to test whether the second criterion is satisfied, following Bartusevičius and Gleditsch (2019) I run a two-part model that has less restrictive identification requirements to assess whether past regime instability have an independent effect on incumbent-led democratic transitions (see Table 3 in the appendix). Results show no statistically significant association between previous number of regime changes and incumbent-led democratic transitions. This suggests that past regime instability is unlikely to have an independent effect on incumbent-led democratic transitions.

Moreover, I include log of autocratic regime duration to control for duration dependence (Carter and Signorino 2010). Doing so makes the estimations mimic standard survival models. Last, I employ country-clustered robust standard errors to account for the panel structure and heteroskedasticity.

\section{Empirical Results}

Table 1 displays the results from the Heckman probit model that simultaneously predicts the likelihood of regime change and incumbent-led democratization as a function of ruling party strength and other covariates. The results are in line with the argument that while ruling party strength decreases the likelihood of a regime change, it increases the likelihood of incumbent-led democratization in autocracies that have experienced a regime change. The estimates of ruling party strength in both equations are above the conventional threshold of statistical significance. This corroborates the expectation that ruling party strength is both a regime strengthening force and a democratizing force. 
Table 1: Ruling Party Strength, Regime Change, and Incumbent-led Democratic Transitions.

\begin{tabular}{lcccc}
\hline \hline & \multicolumn{2}{c}{ Regime Change } & \multicolumn{2}{c}{ Incumbent-led Dem. } \\
\cline { 2 - 5 } & \multicolumn{3}{c}{$(1)$} & \multicolumn{3}{c}{$(2)$} \\
\hline Ruling party strength & $-0.232^{* * *}$ & $(0.056)$ & $0.382^{* *}$ & $(0.155)$ \\
Military & $0.634^{* * *}$ & $(0.109)$ & 0.646 & $(0.856)$ \\
Revolutionary & -0.049 & $(0.162)$ & $0.905^{* *}$ & $(0.440)$ \\
Communist & -0.241 & $(0.201)$ & 0.574 & $(0.559)$ \\
Party age & 0.003 & $(0.002)$ & 0.009 & $(0.008)$ \\
Log oil production per capita & -0.009 & $(0.008)$ & $-0.068^{*}$ & $(0.036)$ \\
Economic growth & 0.232 & $(0.452)$ & $5.090^{* *}$ & $(2.391)$ \\
Log GDP per capita & -0.052 & $(0.074)$ & $0.427^{* *}$ & $(0.198)$ \\
Cold War & $-0.420^{* * *}$ & $(0.135)$ & -0.995 & $(0.683)$ \\
Regional democracy (\%) & -0.372 & $(0.295)$ & 0.824 & $(0.625)$ \\
Log autocracy duration & -0.007 & $(0.063)$ & -0.143 & $(0.140)$ \\
Past regime breakdowns $(\#)$ & $0.026^{* * *}$ & $(0.008)$ & \\
\hline Uncensored & \multicolumn{4}{c}{98} \\
Observations & \multicolumn{4}{c}{-415.474} \\
Log likelihood & \multicolumn{5}{c}{} \\
\hline \hline
\end{tabular}

Heckman probit estimations. Country-clustered standard errors in parentheses. All variables are lagged. The first stage runs a probit estimation of the likelihood of a regime change. The second stage runs a probit estimation of the likelihood of an incumbent-led democratic transition in autocracies that have experienced a regime change ${ }^{*} p<0.10,{ }^{* *}$ $p<0.05,{ }^{* * *} p<0.01$.

To facilitate the interpretation, Figure 1 presents the substantive magnitude of the effects of ruling party strength on the likelihood of regime change. As shown in the figure, shifting ruling party strength up its full range reduces the probability of regime change from 13.9 percent to 1.4 percent. For example, a ruling party that is similar in strength to Kyrgyzstan's White Path Paty $(-2.86)$ is 11 percent more likely to collapse than a party as strong as Lao People's Revolutionary Party in Laos (1.66). 


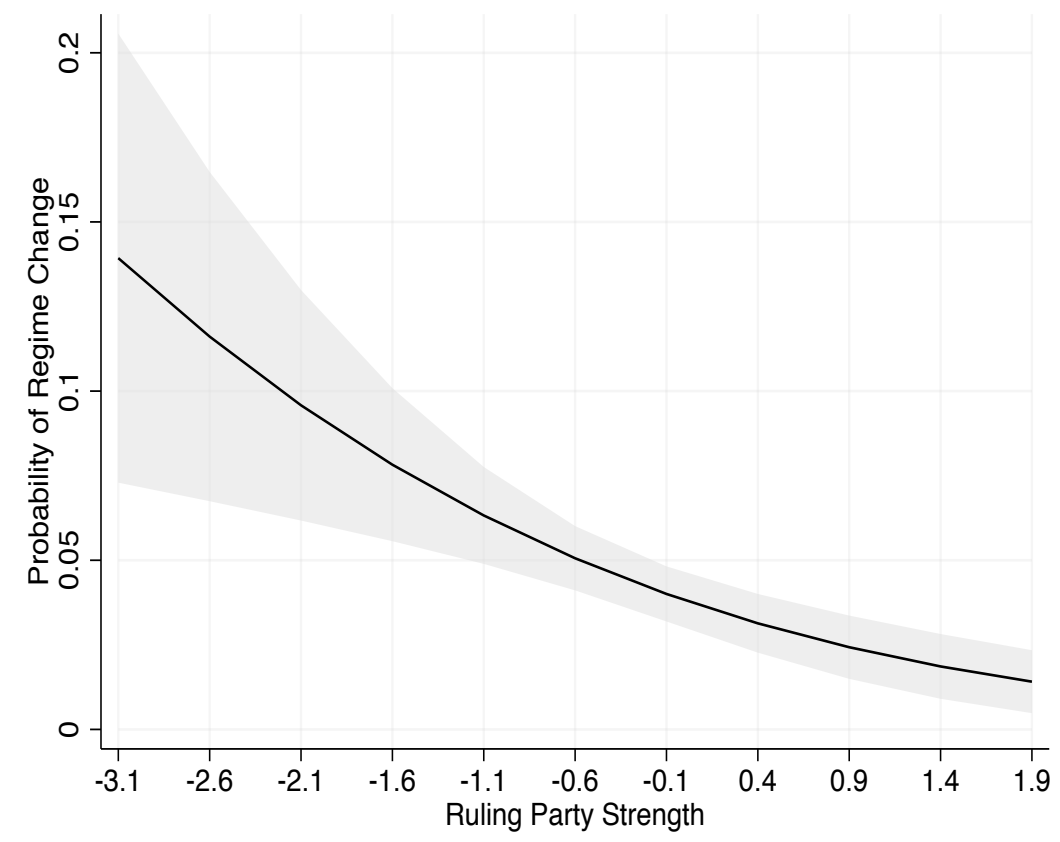

Figure 1: Estimated probabilities (with 95 percent confidence intervals) of regime change based on the first stage probit estimates in Table 1.

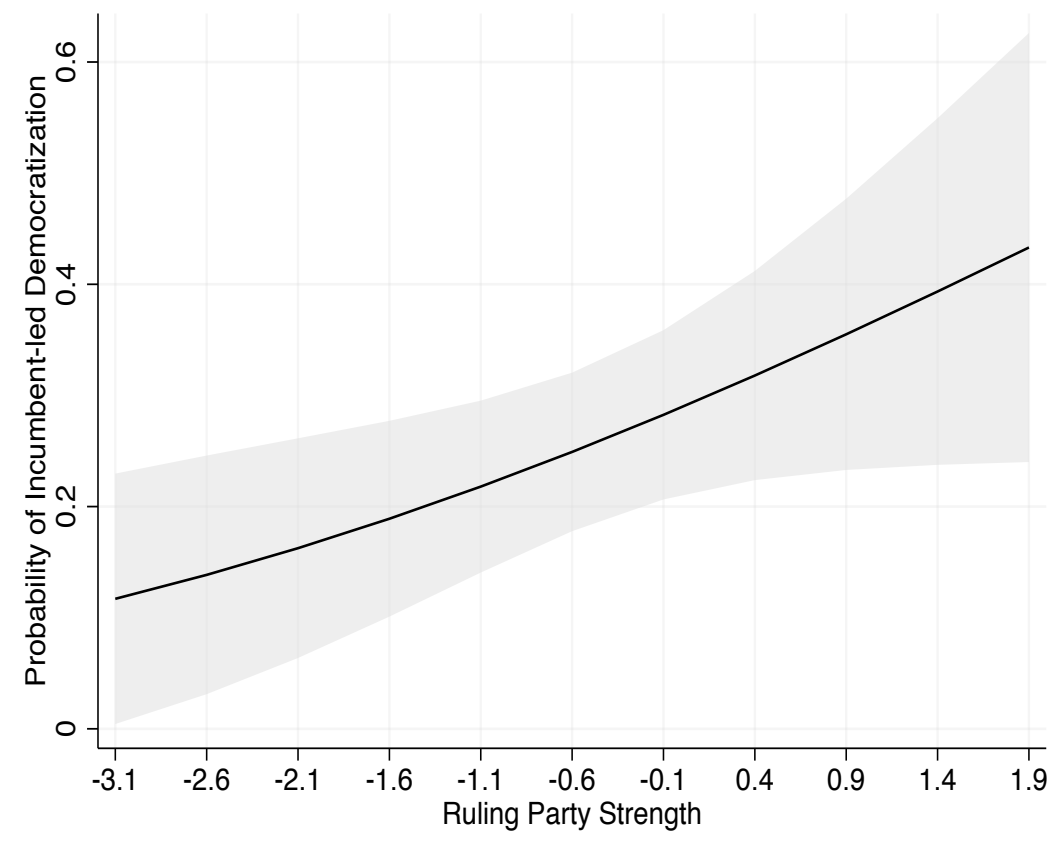

Figure 2: Estimated probabilities (with 95 percent confidence intervals) of incumbent-led democratization based on the second stage probit estimates in Table 1.

Figure 2 graphs the association between ruling party strength and the probability of incumbent-led democratization in the context of regime change. Moving from the lowest 
to the highest ruling party strength increases the probability of incumbent-led democratization from 11.6 percent to 43.3 percent. This shift roughly corresponds to the difference between Peru 2000 (-2.56), which collapsed after the resignation of President Alberto Fujimori amid international pressures and popular protests, and Sandinista National Liberation Front (1.55) of Nicaragua, which has organized competitive elections in 1984 and successfully steered the liberalization process by holding the upper hand in negotiations with the political opposition (Haggard, Kaufman and Teo 2012, p. 80).

Overall, the results support the proposition that strong ruling parties create incentives and capabilities for incumbents to implement democratizing reforms to preempt political opposition during regime transitions. In other words, the findings show that incumbentled democratic transitions is the most likely pathway to regime change in autocracies with strong ruling parties.

Ruling parties' founding origins are also significantly associated with the likelihood of regime change and incumbent-led democratic transitions. Ruling parties founded by military regimes are less durable than parties with other founding origins. ${ }^{4}$ But military founded ruling parties have no impact on incumbent-led democratization. Ruling parties that have originated from revolutionary movements are more durable than other parties but this difference is not statistically significant. Nevertheless, revolutionary ruling parties are significantly more likely to experience regime change in the form of incumbent-led democratization. These results are in line with existing theories. The fragility of ruling parties founded by the military corroborates the studies that suggest military regimes tend to be more short-lived than other regimes (Geddes 1999). One reason why revolutionary parties are more likely to experience incumbent-led democratization might be the tendency of these parties to enjoy high degrees of internal unity and discipline (Levitsky and Way 2012).

Moreover, the results also show that oil production per capita is negatively associated with incumbent-led democratization but have no impact on the likelihood of regime change. This speaks to the study by Houle (2018) who finds that oil reduces the chances that an autocracy will be replaced by a democracy following a regime breakdown. Like 
Kennedy (2010) and Miller (2012) I find that economic development has different implications for regime change and democratization. Table 1 indicates that economic development seems to stabilize autocracies but this association is not statistically significant. Nevertheless, autocracies with higher levels of economic development are more likely to experience incumbent-led democratization than less economically developed autocracies. One potential interpretation of this finding is that economic development might boost the capacity of pro-democratic forces to push for democratic reforms while enhancing the ability of incumbents to respond to such demands by implementing reforms in a top-down fashion. Moreover, the positive impact of economic growth on incumbent-led democratic transition are in line with previous studies that suggest economic growth in the context of regime change enhance incumbents' ability to hold on to power (Haggard and Kaufman 1995).

Finally, the Cold War international environment is negatively associated with the likelihood of regime change and incumbent-led democratization. This highlights the role of external powers in stabilizing regimes as well as in pushing incumbents toward making democratic concessions to domestic opposition groups. Many ruling parties have benefited from the Cold War when there was relatively little pressure for democratization from the West. In the absence of external pressures, autocracies with ruling parties seem to face a lower risk of a regime change. As such, when international donors' demand for democratization is low, autocrats might have few incentives to opt for democratization, which reduces the likelihood of incumbent-led democratization.

I present additional tests in the appendix. First, following Wooldridge (2010), I run an instrumental variable regression for Heckman selection models to account for potential reverse causality between ruling party strength and regime outcomes. In the first step, I use mean regional levels of ruling party strength as an instrument for ruling party strength in a country. This follows from Bizzarro et al. (2018) who argue that political institutions are the product of diffusion in that countries are more likely to adopt particular institutions if their neighbors also adopt them (see also Frantz and KendallTaylor 2017). This should be a valid instrument because it is unlikely that regional levels 
of party strength directly influence the likelihood of incumbent-led democratization in a country. Results from instrumental variable estimations, which are in line with the main findings, are presented in Table 4 in the appendix.

I run additional models controlling for region dummies and a measure of ethnic fractionalization from Nardulli et al. (2012) (see Table 5 and Table 6 in the appendeix). The results are substantively identical to those in Table 1. Last, I run models with reduced forms of the ruling party strength index excluding each individual component. Results from the second stage probit regressions that predict incumbent-led democratization are sensitive to the exclusion of institutionalization and local branches from the index, suggesting that institutionalization and ruling parties' nationwide presence are particularly important for incumbents' ability to guide democratization.

\section{Conclusion}

This study examines the role of autocratic ruling party strength in democratic transitions. Building on existing insights that suggest autocratic incumbents often strategically transition to democracy when the costs of sustaining the autocratic status quo outweigh the costs of democratization (e.g. Acemoglu and Robinson 2005; Riedl et al. 2020; Wright and Escribà-Folch 2012), I contend that ruling party strength can facilitate the implementation of democratizing reforms by incumbent elites in a top-down fashion to preempt political opposition in the context of regime change. An important implication of this argument is that while strong ruling parties generally promote regime durability, they can simultaneously create incentives and capabilities for incumbents to initiate democratizing reforms in an attempt to preserve their privileges in a subsequent democracy.

In particular, this study augments recent insights into the democratizing effect of strong ruling parties (e.g. Riedl et al. 2020) by highlighting how internal party characteristics such as institutionalization and cohesion are key to understanding the conditions under which incumbent-led democratization becomes a likely mode of regime change. My argument suggests that while ruling parties' perceived ability to thwart electoral chal- 
lenges from political opposition might compel incumbents to initiate political reforms, their ability to ensure coordination among regime elites is also a critical source of party strength that shape incumbents' capacity to steer democratization without spiraling into internal struggle. Empirical tests based on a first party-level time-varying measure of ruling party strength corroborate the argument that incumbent-led democratic transitions are especially likely where ruling party qualities that enable regime elites to withstand pressures from outsider opposition groups are complemented with internal party attributes that promote elite coordination within the ruling coalition.

Future work should analyze the implications of democratizing reforms implemented by strong ruling parties for democratic development in the post-transition era. A growing body of literature analyzes how former autocratic ruling parties influence the prospects of democratic consolidation in the long-term (e.g. Grzymala-Busse 2020; Miller 2019; Riedl 2014). Future work can examine how the modes of democratic transition can condition the impact of former autocratic ruling parties on democratic development. Given that most contemporary regime transitions are from autocracies with ruling parties, how these parties influence democratization will remain an important topic of research.

\section{Notes}

${ }^{1}$ Like Riedl et al. (2020), I do not assume that incumbents always intend to fully democratize their regimes. Instead, incumbents often aim to keep reforms limited, but initial liberalizing reforms may lead to stronger democratic institutions that can consequently result in a transition to democracy.

${ }^{2}$ In a way, this is similar to Brownlee (2009) who estimate two equations independently. Importantly, however, following recent studies I estimate the outcomes simultaneously (e.g. Houle, Kayser and Xiang 2016; Kennedy 2010).

${ }^{3}$ If the exact regressors are included in both equations, the model is identified through assumptions about the residual distribution (Sartori 2003).

${ }^{4}$ The reference category includes parties founded through elite coalitions, created by dictators after the seizure of power, and independence movements. Please see Miller (2020) for a detailed description of these categories.

\section{References}

Acemoglu D and Robinson JA (2005) Economic Origins of Dictatorship and Democracy. New York: Cambridge University Press.

Albertus M and Gay V (2017) Unlikely democrats: Economic elite uncertainty under dictatorship and support for democratization. American Journal of Political Science 61(3): 624-641. 
Albertus M and Menaldo V (2018) Authoritarianism and the Elite Origins of Democracy. New York: Cambridge University Press.

Bartusevičius H and Gleditsch KS (2019) A two-stage approach to civil conflict: Contested incompatibilities and armed violence. International Organization 73(1): 225248.

Bernhard M and Edgell AB and Lindberg SI (2020) Institutionalising electoral uncertainty and authoritarian regime survival. European Journal of Political Research 59(2): $465-487$.

Bizzarro F, Gerring J, Knutsen CH, Hicken A, Bernhard M, Skaaning S-E, Coppedge M and Lindberg SI (2018) Party strength and economic growth. World Politics 70(2): $275-320$.

Blaydes L (2010) Elections and distributive politics in Mubarak's Egypt. New York: Cambridge University Press

Boix C, Miller M and Rosato S (2013) A complete data set of political regimes, 1800-2007. Comparative Political Studies 46(12): 1523-1554.

Boix C and Stokes SC (2003) Endogenous democratization. World politics 55(4): $517-549$.

Boix C and Svolik MW (2013) The foundations of limited authoritarian government: Institutions, commitment, and power-sharing in dictatorships. The Journal of Politics $75(2): 300-316$.

Boix C (2003)Democracy and Redistribution. New York: Cambridge University Press.

Bolt J, Inklaar Robert, de Jong H, Van Zanden JL (2018) Rebasing 'Maddison': new income comparisons and the shape of long-run economic development. GGDC Research Memorandum, University of Gronningen 174.

Brownlee J (2007) Authoritarianism in an Age of Democratization. New York: Cambridge University Press.

Brownlee J (2009) Portents of pluralism: How hybrid regimes affect democratic transitions. American Journal of Political Science 53(3): 515-532.

Carter DB and Signorino CS (2010) Back to the future: Modeling time dependence in binary data. Political Analysis 18(3): 271-292.

Coppedge M, Gerring J, Knutsen CH, Lindberg SI, Teorell J, Altman D, Bernhard M, Fish MS, Glynn A, Hicken A, Lührmann A, Marquardt KL, McMann K, Paxton P, Pemstein D,Seim B, Sigman R, Skaaning S-E, Staton J, Wilson S, Cornell A, Alizada N, Gastaldi L, Gjerløw H, Hindle G, Ilchenko N, Maxwell L, Mechkova V, Medzihorsky J, von Römer J, Sundström A, Tzelgov E, Wang Y, Wig T and Ziblatt D (2020) V-Dem Country-Year Dataset v10. Gothenburg: Varieties of Democracy (V-Dem) Project. https://doi.org/10.23696/vdemds20.

Debs A (2016) Living by the sword and dying by the sword? Leadership transitions in and out of dictatorships. International Studies Quarterly 60(1): 73-84. 
Djuve VL, Knutsen CH and Wig T (2020) Patterns of regime breakdown since the French revolution. Comparative Political Studies 53(6): 923-958.

Frantz E and Kendall-Taylor A (2017) Pathways to democratization in personalist dictatorships. Democratization 24(1): 20-40.

Geddes B (1999) What do we know about democratization after twenty years? Annual Review of Political Science 2(1): 115-144.

Geddes B., Wright J and Frantz E (2014) Autocratic breakdown and regime transitions: A new data set. Perspectives on Politics 12(2): 313-331.

Geddes B, Wright J and Frantz E (2018) How Dictatorships Work: Power, Personalization, and Collapse. New York: Cambridge University Press.

Gehlbach S and Keefer P (2011) Investment without democracy: Ruling-party institutionalization and credible commitment in autocracies. Journal of Comparative Economics 39(2): 123-139.

Gisselquist RM (2008) Democratic transition and democratic survival in Benin. Democratization 15(4): 789-814.

Greene KF (2007) Why Dominant Parties Lose: Mexico's Democratization in Comparative Perspective. Cambridge University Press.

Grzymala-Busse A (2020) Consequences of authoritarian party exit and reinvention for democratic competition Comparative Political Studies. Epub ahead of print 16 Februarty 2020. DOI: 10.1177/0010414019897683.

Haggard S and Kaufman R (1995) The political economy of democratic transitions. Princeton University Press.

Haggard S, Kaufman R and Teo T. (2012) Distributive conflict and regime change: A qualitative dataset. https://doi.org/10.7910/DVN/O0GKQK.

Heckman J. (1979) Sample selection bias as a specification error. Applied Econometrics $31(3): 129-137$.

Houle C (2018) A two-step theory and test of the oil curse: the conditional effect of oil on democratization. Democratization 25(3):404-421.

Houle C, Kayser MA and Xiang J (2016) Diffusion or confusion? clustered shocks and the conditional diffusion of democracy. International Organization 70(4): 687-726.

Huntington SP (1968) Political Order in Changing Societies. Yale University Press.

Kennedy R (2010) The contradiction of modernization: A conditional model of endogenous democratization. The Journal of Politics 72(3): 785-798.

Levitsky S (1998) Institutionalization and peronism: The concept, the case and the case for unpacking the concept, Party politics 4 (1): 77-92.

Levitsky S and Way L (2012) Beyond patronage: Violent struggle, ruling party cohesion, and authoritarian durability. Perspectives on Politics 10(4): 869-889. 
Levitsky S and Way L (2010) Competitive Authoritarianism: Hybrid Regimes after the Cold War. New York: Cambridge University Press.

Lührmann A, Düpont N, Higashijima M, Kavasoglu YB, Marquardt KL, Bernhard M, Döring H, Hicken A, Laebens M, Lindberg SI, Neundorf A, Ruth S, Weghorst KR, Wiesehomeier N, Wright J, Reuter OJ, Alizada N, Gastaldi L, Grahn S, Hindle G, Ilchenko N, von Römer J, Pemstein D and Seim B (forthcoming) V-Party: The Varieties of Party Identity and Organization Dataset Gothenburg: Varieties of Democracy (V-Dem) Project.

Magaloni B (2006) Voting for Autocracy: Hegemonic Party Survival and its Demise in Mexico. New York: Cambridge University Press.

Magaloni B (2008) Credible power-sharing and the longevity of authoritarian rule. Comparative Political Studies 41(4): 715-741.

Magaloni B. and Kricheli R (2010) Political order and one-party rule. Annual Review of Political Science 13: 123-143.

Malesky E and Schuler P (2010) Nodding or needling: Analyzing delegate responsiveness in an authoritarian parliament. American Political Science Review 104(3), 482-502.

Meng A (2019) Ruling parties in authoritarian regimes: Rethinking institutional strength. British Journal of Political Science. Epub ahead of print 25 September 2019. DOI: 10.1017/S0007123419000115

Miller MK (2012) Economic development, violent leader removal, and democratization. American Journal of Political Science 56(4): 1002-1020.

Miller MK (2019) Don't call it a comeback: Autocratic ruling parties after democratization. British Journal of Political Science. Epub ahead of print 27 August 2019. DOI: 10.1017/S0007123419000012

Miller MK (2020) The autocratic ruling parties dataset: Origins, durability, and death, Journal of Conflict Resolution 64(4): 756-782.

Morse YL (2018) How autocrats compete: Parties, patrons, and unfair elections in Africa. New York: Cambridge University Press.

Nardulli PF, Wong CJ, Singh A, Peyton B and Bajjaliegh J (2012) The composition of religious and ethnic groups (CREG) project. http://www.clinecenter.illinois.edu/publications/CREG-White. pdf.

O'Donnell G and Schmitter PC (1986) Transitions from Authoritarian rule: Tentative Conclusions about Uncertain Democracies. JHU Press.

Panebianco A (1988) Political parties: Organization and Power. New York: Cambridge University Press.

Pemstein D, Marquardt KL, Tzelgov E, Wang Y, Medzihorsky J, Krusell J, Miri F and von Römer J (2020) The V-Dem measurement model: Latent variable analysis for cross-national and cross-temporal expert-coded data. Varieties of Democracy Institute Working Paper 21. https://www.v-dem.net/en/news-publications/working-papers/. 
Przeworski A (1991) Democracy and the market: Political and Economic Reforms in Eastern Europe and Latin America. New York: Cambridge University Press.

Reuter OJ (2017) The origins of Dominant Parties: Building Authoritarian Institutions in post-Soviet Russia. New York: Cambridge University Press.

Reuter OJ and Gandhi J (2011) Economic performance and elite defection from hegemonic parties. British Journal of Political Science 41(1): 83-110.

Reuter OJ and Szakonyi D (2019) Elite defection under autocracy: Evidence from Russia. American Political Science Review 113(2): 552-568.

Riedl RB (2014) Authoritarian Origins of Democratic Party Systems in Africa. New York: Cambridge University Press.

Riedl RB., Slater D, Wong J and Ziblatt D (2020) Authoritarian-led democratization. Annual Review of Political Science 23.

Ross M and Mahdavi P (2015) Oil and gas data, 1932-2014, version 2. https://doi.org/10.7910/DVN/ZTPW0.

Sartori AE (2003) An estimator for some binary-outcome selection models without exclusion restrictions. Political Analysis 11(2): 111-138.

Slater D (2010) Ordering Power: Contentious Politics and Authoritarian Leviathans in Southeast Asia. New York: Cambridge University Press.

Slater D and Wong J (2013) The strength to concede: Ruling parties and democratization in developmental Asia. Perspectives on Politics 11(3): 717-733.

Smith B (2005) Life of the party: The origins of regime breakdown and persistence under single-party rule. World politics 57(3): 421-451.

Svolik MW (2012) The Politics of Authoritarian Rule. New York: Cambridge University Press.

Van de Walle N (2006) Tipping games: When do opposition parties coalesce? In: Schedler A (eds). Electoral Authoritarianism: The Dynamics of Unfree Competition. Boulder: Lynne Rienner, pp. 77-94.

Wooldridge JM (2010) Econometric Analysis of Cross Section and Panel Data. MIT press.

Wright J and Escribà-Folch A (2012) Authoritarian institutions and regime survival: Transitions to democracy and subsequent autocracy. British Journal of Political Science 42(2): 283-309.

Ziblatt D (2017) Conservative Political Parties and the Birth of Modern Democracy in Europe. New York: Cambridge University Press. 


\section{Appendix}

\section{Measuring ruling party strength}

\section{V-Party Expert Survey Questionnaire}

1. Local party branches

Question: Does this party maintain permanent offices that operate outside of election campaigns at the local or municipal-level?

Clarification: By "local or municipal" we mean low level administrative divisions that are ranked below regions, provinces, or states. We refer to offices that maintain professional personnel and continued interaction of the party with citizens. Permanent offices operate outside of election campaigns.

Responses:

0 : The party does not have permanent local offices.

1: The party has permanent local offices in few municipalities.

2: The party has permanent local offices in some municipalities.

3: The party has permanent local offices in most municipalities.

4: The party has permanent local offices in all or almost all municipalities.

\section{Local organizational strength}

Question: To what degree are party activists and personnel permanently active in local communities?

Clarification: Please consider the degree to which party activists and personnel are active both during election and non-election periods. Party personnel refers to paid staff.

Responses:

0: There is negligible permanent presence of party activists and personnel in local communities.

1: There is minor permanent presence of party activists and personnel in local communities.

2: There is noticeable permanent presence of party activists and personnel in local communities.

3: There is significant permanent presence of party activists and personnel in local communities.

4: There is widespread permanent presence of party activists and personnel in local communities.

\section{Affiliate organizations}

Question: To what extent does this party maintain ties to prominent social organizations?

Clarification: When evaluating the strength of ties between the party and social organizations please consider the degree to which social organizations contribute to party operations by providing material and personnel resources, propagating the party's message to its members and beyond, as well as by directly participating in the party's electoral campaign and/or mobilization efforts. Social organizations include: Religious organizations (e.g. churches, sects, charities), trade unions/syndical organizations or cooperatives, cultural and social associations (e.g. sports clubs, neighborhood associations), political associations (e.g. environmental protection) and professional and business associations. Social organizations do not include paramilitary units or militias.

Responses:

0: The party does not maintain ties to any prominent social organization.

1: The party maintains weak ties to prominent social organizations.

2: The party maintains moderate ties to prominent social organizations.

3: The party maintains strong ties to prominent social organizations.

4: The party controls prominent social organizations.

4. Internal cohesion

Question: To what extent do the elites in this party display disagreement over party strategies?

Clarification: Party strategies include election campaign strategy, policy stance, distribution of party financial resources, cooperation with other parties (i.e. coalition formation), and the selection of legislative and presidential candidates as well as the party leader. Party elites are prominent 
and influential party members such as current and former ministers, members of parliament or the party leadership, regional and municipal leaders, and opinion leaders. They do not necessarily have to be the part of the official party leadership.

Responses:

0: Party elites display almost complete disagreement over party strategies and many party elites have left the party.

1: Party elites display a high level of visible disagreement over party strategies and some of them have left the party.

2: Party elites display some visible disagreement over party strategies, but none of them have left the party.

3: Party elites display negligible visible disagreement over party strategies.

4: Party elites display virtually no visible disagreement over party strategies.

5. Personalization of party

Question: To what extent is this party a vehicle for the personal will and priorities of one individual leader?

Responses:

0: The party is not focused on the personal will and priorities of one individual leader.

1: The party is occasionally focused on the personal will and priorities of one individual party leader.

2: The party is somewhat focused on the personal will and priorities of one individual party leader.

3: The party is mainly focused on the personal will and priorities of one individual party leader.

4: The party is solely focused on the personal will and priorities of one individual party leader.

This indicator is reversed so that higher values indicate more institutionalization. 


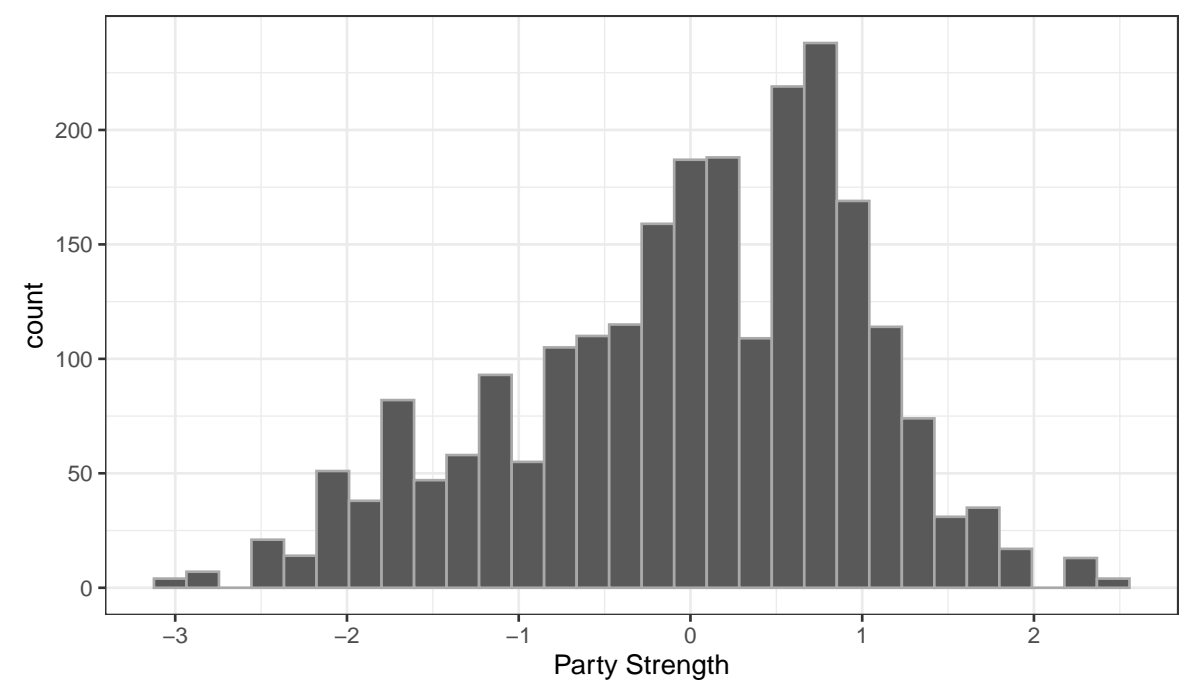

Figure 3: Histogram of the ruling party strength index. 


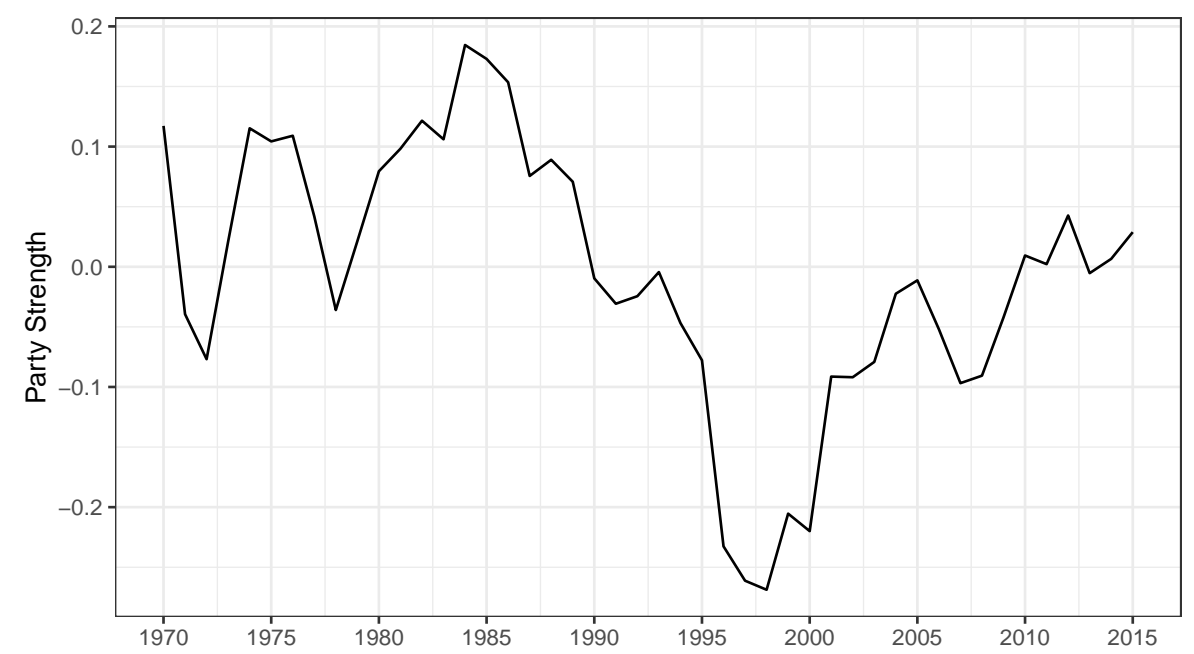

Figure 4: Average ruling party strength in autocracies (1970 - 2015). 


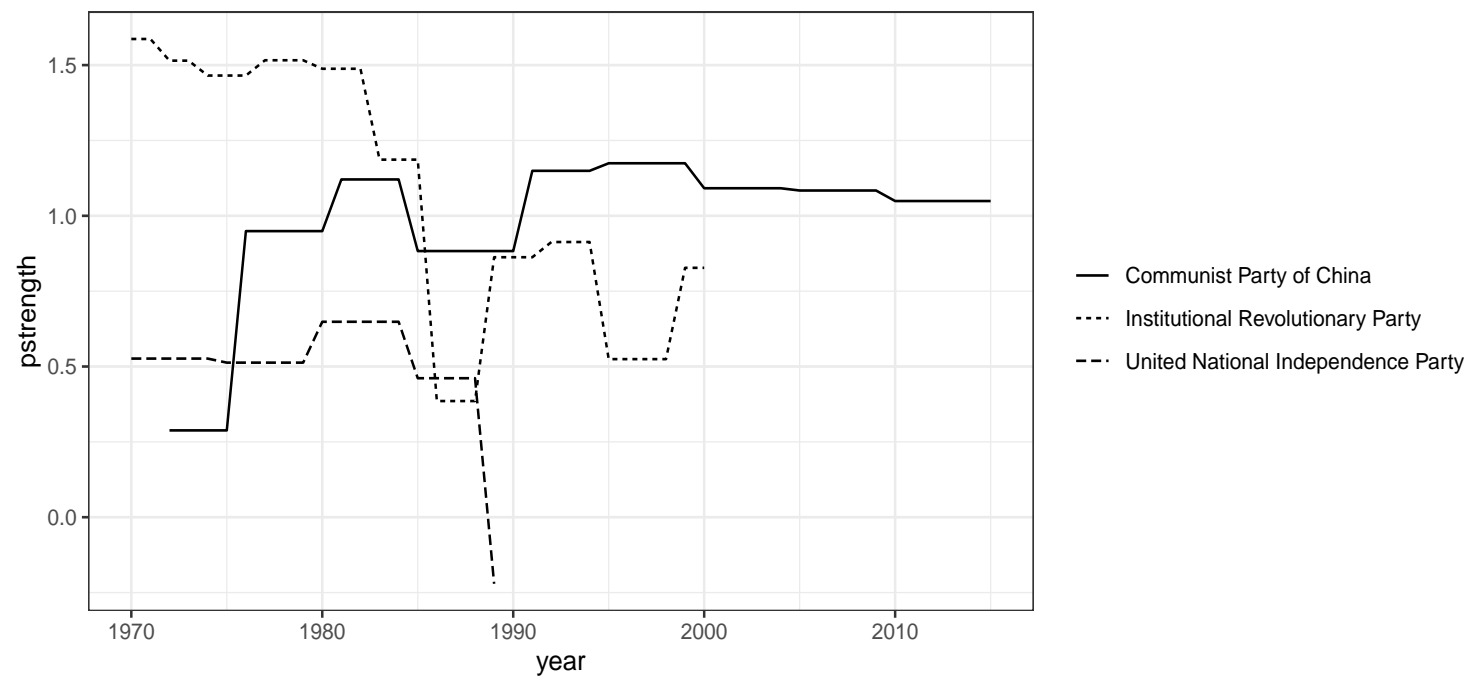

Figure 5: Ruling Party strength in selected countries.

Figure 3 presents changes in ruling party strength over time in three selected cases. Th figure shows that Communist Party of China has become significantly more powerful over time. The steep increase in the party's strength after 1975 captures the implementation of more institutionalized and collegial decision-making procedures following the death of the regime's founding leader Mao Zedong. As for Mexico's Institutional Revolutionary Party the measure drops significantly around 1985, when the followers of Cuauhtémoc Cárdenas has defected to form an opposition party. There is also a significant drop in party strength in the period leading up to the 1997 parliamentary elections in which the party lost its absolute majority in the parliament for the first time. As for Zambia's United National Independence Party, there is a significant drop in party strength in the run up to the multiparty elections in 1990, which was won by the opposition Movement for Multiparty Democracy. 


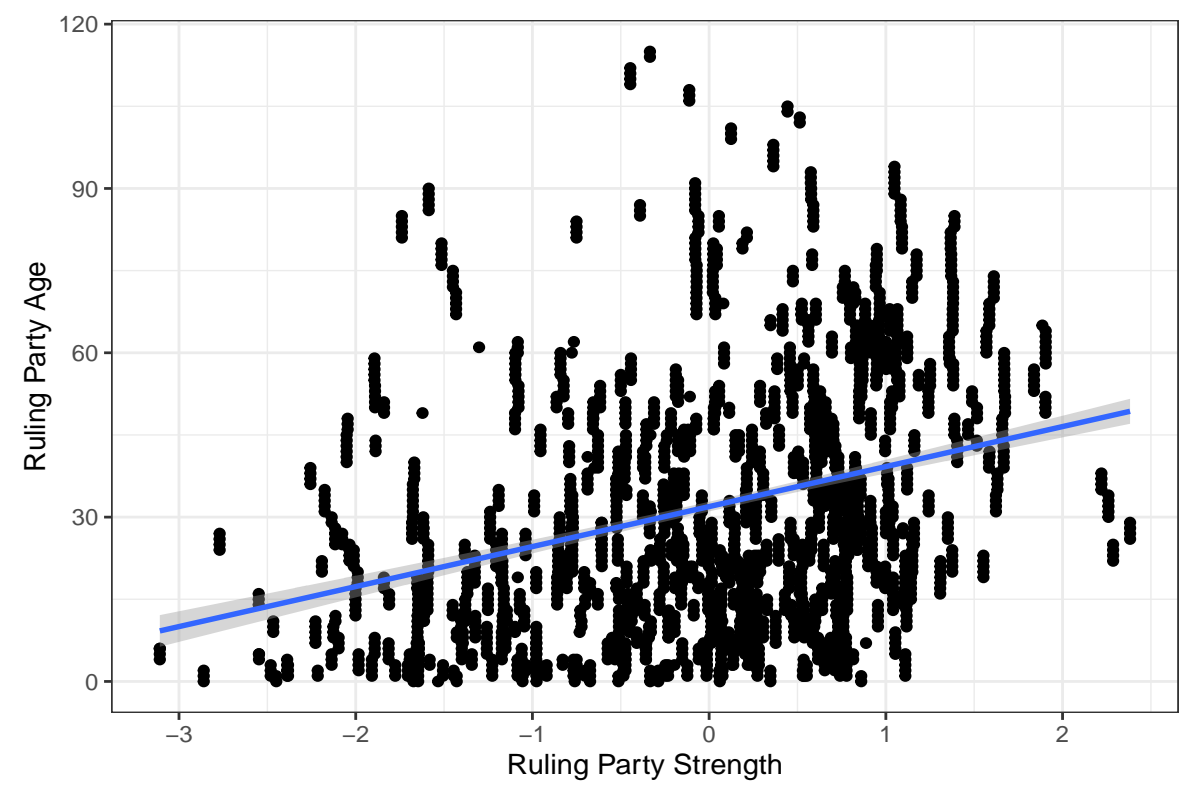

Figure 6: The relationship between ruling party strength and ruling party age. 

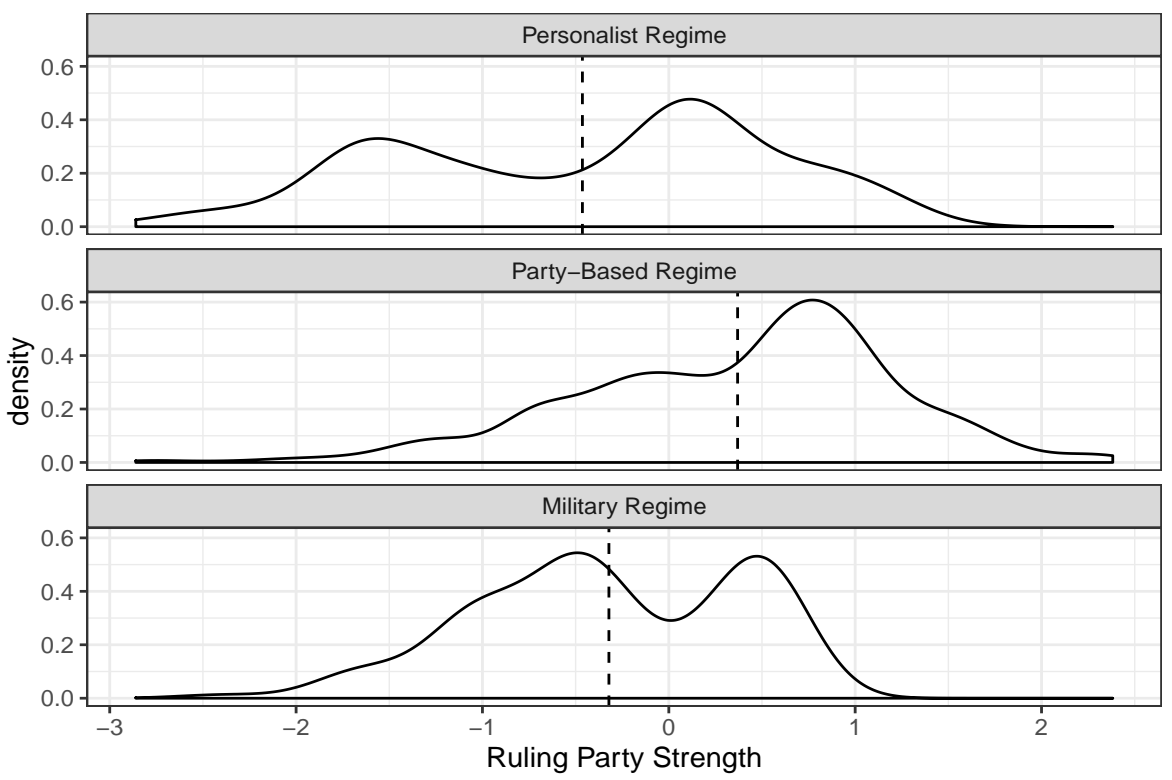

Figure 7: Ruling party strength across Geddes et al. (2014) regime types. 


\section{Overview of regime transitions}

\begin{tabular}{|c|c|c|}
\hline \multicolumn{2}{|c|}{ Other $(N: 67)$} & Incumbent-led $(N: 31)$ \\
\hline Paraguay 1988 & Cambodia 1978 & Hungary 1989 \\
\hline El Salvador 1979 & Rwanda 1993 & Paraguay $2002^{*}$ \\
\hline Czechoslavakia 1989 & El Salvador 1983 & Bulgaria 1990 \\
\hline Poland 1989 & Cambodia 1975 & Nicaragua 1984 \\
\hline Panama 1989 & Comoros 1998 & Taiwan 1996 \\
\hline Ecuador 2002 & Iraq 2014 & Brazil 1984 \\
\hline Croatia 1999 & Niger 1999 & South Africa 1994 \\
\hline Georgia 2003 & & Mexico 2000 \\
\hline Bangladesh 1975 & & Albania 1991 \\
\hline Indonesia 1999 & & Sri Lanka 1994 \\
\hline Bangladesh 1990 & & Ghana 1996 \\
\hline Egypt 2011 & & Mozambique $1994^{*}$ \\
\hline Senegal 1999 & & Kenya 2002 \\
\hline Pakistan 2008 & & Mongolia 1989 \\
\hline Bangladesh 1981 & & Zambia $2007^{*}$ \\
\hline Seychelles 1976 & & Nigeria $2014^{*}$ \\
\hline Sierra Leone 1991 & & Niger 1992 \\
\hline Sierra Leone 1997 & & Malawi 1994 \\
\hline Algeria 1991 & & Lesotho 2001 \\
\hline Guinea-Bissau 2004 & & Cape Verde 1990 \\
\hline Guinea-Bissau 1979 & & Seychelles 2015 \\
\hline Guinea-Bissau 1999 & & Sierra Leone 2001 \\
\hline Burkina Faso 2014 & & Guyana 1991 \\
\hline Armenia 1998 & & South Korea 1987 \\
\hline South Korea 1971 & & Sao Tome and Principe 1991 \\
\hline South Korea 1979 & & Spain 1976 \\
\hline Central African Republic 1979 & & Central African Republic 1993 \\
\hline Guinea 1984 & & Myanmar 2015 \\
\hline Portugal 1973 & & Tunisia 2013 \\
\hline Tunisia 2010 & & Gabon 1990 \\
\hline Soviet Union 1991 & & Burundi 2005 \\
\hline Central African Republic 2013 & & \\
\hline Philippines 1985 & & \\
\hline Haiti 2000 & & \\
\hline Haiti 1985 & & \\
\hline Haiti 2011 & & \\
\hline Somalia 1990 & & \\
\hline Mauritania 2005 & & \\
\hline Mauritania 1978 & & \\
\hline Comoros 1989 & & \\
\hline Madagascar 1992 & & \\
\hline Niger 1973 & & \\
\hline Iraq 2002 & & \\
\hline Madagascar 1972 & & \\
\hline Mali 1990 & & \\
\hline Kyrgyzstan 2009 & & \\
\hline Benin 1990 & & \\
\hline Burkina Faso 1980 & & \\
\hline Guinea 2008 & & \\
\hline Tunisia 1987 & & \\
\hline Cameroon 1983 & & \\
\hline Ethiopia 1990 & & \\
\hline Myanmar 1987 & & \\
\hline Iran 1978 & & \\
\hline
\end{tabular}


* Not coded as regime change in Djuve et al. (2020) but coded as democratic transition in Miller (2020). I coded these democratic transitions as incumbent-led because substantial democratization has occurred under the guidance of the ruling party. In all three cases, ruling parties remained in power despite of democratization. 


\section{Summary statistics}

\begin{tabular}{lccccccc}
\hline \hline & $\mathrm{N}$ & Mean & St. Dev. & Min & Pctl(25) & Pctl(75) & Max \\
\hline Ruling party strength & 2,286 & -0.000 & 1.000 & -3.097 & -0.624 & 0.759 & 2.373 \\
Institutionalization & 2,286 & 0.000 & 1.000 & -1.944 & -0.753 & 0.662 & 2.593 \\
Internal cohesion & 2,286 & 0.000 & 1.000 & -2.959 & -0.763 & 0.962 & 1.613 \\
Local org. strength & 2,286 & -0.000 & 1.000 & -3.733 & -0.727 & 0.799 & 1.885 \\
Local branches & 2,286 & -0.000 & 1.000 & -3.679 & -0.481 & 0.712 & 1.366 \\
Affiliate org. & 2,286 & -0.000 & 1.000 & -3.423 & -0.606 & 0.820 & 1.627 \\
Military & 2,286 & 0.047 & 0.212 & 0 & 0 & 0 & 1 \\
Revolutionary & 2,286 & 0.136 & 0.342 & 0 & 0 & 0 & 1 \\
Communist & 2,286 & 0.182 & 0.386 & 0 & 0 & 0 & 1 \\
Party age & 2,286 & 32.094 & 23.239 & 0 & 13 & 48 & 115 \\
Economic growth & 2,286 & 0.023 & 0.093 & -0.840 & -0.017 & 0.065 & 0.898 \\
Log oil production per capita & 2,286 & 7.344 & 7.999 & 0.000 & 0.000 & 15.849 & 20.239 \\
Log GDP per capita & 2,286 & 8.079 & 0.925 & 5.922 & 7.368 & 8.771 & 11.114 \\
Cold War & 2,286 & 0.462 & 0.499 & 0 & 0 & 1 & 1 \\
Regional democracy (\%) & 2,286 & 0.281 & 0.219 & 0 & 0.1 & 0.4 & 1 \\
Past regime breakdowns $(\#)$ & 2,286 & 7.109 & 6.364 & 0 & 3 & 9 & 35 \\
log autocracy duration & 2,286 & 3.331 & 0.958 & 0.000 & 2.773 & 3.892 & 5.375 \\
Ethnic fractionalization & 1,796 & 0.482 & 0.278 & 0.003 & 0.216 & 0.762 & 0.884 \\
\hline
\end{tabular}




\section{Additional Tests}

Table 3: Two-part logistic regression.

\begin{tabular}{lcccc}
\hline \hline & \multicolumn{2}{c}{$(1)$} & \multicolumn{2}{c}{$(2)$} \\
& \multicolumn{2}{c}{ Regime Change } & \multicolumn{2}{c}{ Incumbent-led Dem. } \\
\hline Ruling party strength & $-0.504^{* * *}$ & $(0.125)$ & $0.549^{* *}$ & $(0.275)$ \\
Military & $1.352^{* * *}$ & $(0.221)$ & 1.453 & $(1.121)$ \\
Revolutionary & -0.225 & $(0.357)$ & $1.848^{* *}$ & $(0.918)$ \\
Communist & -0.580 & $(0.491)$ & 1.004 & $(1.022)$ \\
Party age & $0.00903^{*}$ & $(0.00536)$ & 0.0201 & $(0.0138)$ \\
Log oil production per capita & -0.0196 & $(0.0178)$ & $-0.159^{*}$ & $(0.0850)$ \\
Economic growth & 0.532 & $(0.981)$ & $10.85^{* *}$ & $(5.073)$ \\
Log GDP per capita & -0.136 & $(0.167)$ & $0.808^{* *}$ & $(0.352)$ \\
Cold War & $-0.931^{* * *}$ & $(0.304)$ & $-2.366^{* *}$ & $(0.990)$ \\
Regional democracy $(\%)$ & -0.915 & $(0.675)$ & 1.109 & $(1.199)$ \\
Past regime breakdowns $(\#)$ & $0.0536^{* * *}$ & $(0.0193)$ & 0.0275 & $(0.0502)$ \\
log autocracy duration & -0.0216 & $(0.137)$ & -0.260 & $(0.320)$ \\
\hline Uncensored & \multicolumn{5}{c}{98} \\
Observations & \multicolumn{5}{c}{2286} \\
\hline \hline
\end{tabular}

Country-clustered standard errors in parentheses. The first stage equation runs a logit estimation of the likelihood of regime change. The second stage equation runs a logit estimation of likelihood of incumbent-led democratization among the cases that have experienced a regime change. The coefficient for the number of regime breakdown is significant in the first stage equation but not in the second stage, which supports my argument that past regime instability should have no independent effect on incumbent-led democratization. ${ }^{*} p<0.10,{ }^{* *}$ $p<0.05,{ }^{* * *} p<0.01$. 
Table 4: Heckman probit estimations (Insturmental variable estimation)

\begin{tabular}{|c|c|c|c|c|c|c|}
\hline \multirow[b]{3}{*}{ Regional ruling party strength } & \multirow{2}{*}{\multicolumn{2}{|c|}{$\begin{array}{l}\text { First-Stage Regression } \\
\text { Ruling Party strength }\end{array}$}} & \multicolumn{4}{|c|}{ Second-Stage Regression } \\
\hline & & & \multicolumn{2}{|c|}{ Regime Change } & \multicolumn{2}{|c|}{ Incumbent-led Dem. } \\
\hline & $0.960^{* * *}$ & $(0.0379)$ & & & & \\
\hline Ruling party strength & & & $-0.262^{* * *}$ & $(0.0623)$ & $0.347^{* *}$ & $(0.174)$ \\
\hline Military & 0.140 & $(0.128)$ & $0.681^{* * *}$ & $(0.119)$ & 0.673 & $(0.863)$ \\
\hline Revolutionary & 0.0207 & $(0.0777)$ & -0.0453 & $(0.170)$ & $0.933^{* *}$ & $(0.440)$ \\
\hline Communist & $0.655^{* * *}$ & $(0.123)$ & -0.220 & $(0.199)$ & 0.568 & $(0.557)$ \\
\hline Party age & 0.000659 & $(0.00202)$ & 0.00343 & $(0.00262)$ & 0.0102 & $(0.00783)$ \\
\hline Log oil production per capita & -0.000214 & $(0.00699)$ & -0.00904 & $(0.00863)$ & $-0.0734^{* *}$ & $(0.0363)$ \\
\hline Economic growth & 0.136 & $(0.123)$ & 0.0302 & $(0.500)$ & $5.627^{* *}$ & $(2.256)$ \\
\hline Log GDP per capita & $0.104^{*}$ & $(0.0622)$ & -0.0733 & $(0.0821)$ & $0.486^{* *}$ & $(0.212)$ \\
\hline Cold War & 0.0432 & $(0.0546)$ & $-0.432^{* * *}$ & $(0.139)$ & -0.947 & $(0.634)$ \\
\hline Regional democracy (\%) & $-0.340^{* *}$ & $(0.168)$ & -0.383 & $(0.311)$ & 0.788 & $(0.645)$ \\
\hline Past regime breakdowns (\#) & 0.00731 & $(0.00649)$ & $0.0278^{* * *}$ & $(0.00918)$ & & \\
\hline log autocracy duration & $0.0794^{*}$ & $(0.0426)$ & 0.00694 & $(0.0724)$ & -0.194 & $(0.161)$ \\
\hline Observations & \multicolumn{2}{|c|}{2286} & \multicolumn{4}{|c|}{2286} \\
\hline Log Lik. & \multirow{2}{*}{\multicolumn{2}{|c|}{0.88}} & \multirow{2}{*}{\multicolumn{4}{|c|}{-404.6}} \\
\hline $\mathrm{R}^{2}$ & & & & & & \\
\hline
\end{tabular}

Redoes the main heckman probit model using average regional ruling party strength as an instrument for ruling party strength in a country. Country-clustered standard errors in parentheses. ${ }^{*} p<0.10,{ }^{* *} p<0.05$, *** $p<0.01$. 
Table 5: Controlling for ethnic fractionalization.

\begin{tabular}{lcccc}
\hline \hline & Regime Change & \multicolumn{3}{c}{ Incumbent-led Dem. } \\
\hline Ruling party strength & $-0.256^{* * *}$ & $(0.0662)$ & $0.271^{*}$ & $(0.142)$ \\
Military & $0.662^{* * *}$ & $(0.106)$ & 0.220 & $(0.571)$ \\
Revolutionary & -0.130 & $(0.200)$ & 0.773 & $(0.485)$ \\
Communist & -0.201 & $(0.217)$ & 0.778 & $(0.490)$ \\
Party age & 0.00357 & $(0.00262)$ & 0.00760 & $(0.00741)$ \\
Log oil production per capita & -0.0109 & $(0.0108)$ & -0.0548 & $(0.0413)$ \\
Economic growth & 0.0129 & $(0.499)$ & 3.946 & $(2.740)$ \\
Log GDP per capita & -0.0588 & $(0.109)$ & $0.471^{*}$ & $(0.273)$ \\
Ethnic fracitonalization & $-0.443^{* *}$ & $(0.209)$ & $1.331^{* *}$ & $(0.582)$ \\
Cold War & $-0.497^{* * *}$ & $(0.144)$ & -0.430 & $(0.662)$ \\
Regional democracy (\%) & -0.277 & $(0.306)$ & 0.520 & $(0.515)$ \\
Log autocracy duration & 0.00315 & $(0.0712)$ & & \\
Past regime breakdowns $(\#)$ & 0.0149 & $(0.00923)$ & & \\
\hline Uncensored & \multicolumn{3}{c}{82} & \\
Observations & \multicolumn{3}{c}{-337.9} & \\
Log lik. & \multicolumn{3}{c}{} \\
\hline \hline
\end{tabular}

This model adds a measure of ethnic fractionalization to the main Heckman probit model. Country clustered standard errors in parentheses. Ethnic fractionalization variable has many missing observations, which reduce the number of regime change events. ${ }^{*} p<0.10,{ }^{* *} p<0.05,{ }^{* * *} p<0.01$. 
Table 6: Controlling for region dummies.

\begin{tabular}{lcccc}
\hline \hline & \multicolumn{3}{c}{ Regime Change } & \multicolumn{2}{c}{ Incumbent-led Dem. } \\
\hline Ruling Party Strength & $-0.267^{* * *}$ & $(0.0574)$ & $0.447^{* * *}$ & $(0.146)$ \\
Military & $0.614^{* * *}$ & $(0.146)$ & 0.464 & $(0.715)$ \\
Revolutionary & -0.0752 & $(0.155)$ & $1.119^{* *}$ & $(0.547)$ \\
Communist & $-0.685^{* *}$ & $(0.266)$ & $1.731^{* *}$ & $(0.877)$ \\
Party age & $0.00538^{* *}$ & $(0.00268)$ & 0.00490 & $(0.00693)$ \\
Log oil production per capita & -0.0117 & $(0.00811)$ & -0.0416 & $(0.0357)$ \\
Economic growth & 0.229 & $(0.459)$ & $4.697^{*}$ & $(2.537)$ \\
Log GDP per capita & $-0.125^{*}$ & $(0.0715)$ & $0.746^{* *}$ & $(0.301)$ \\
Cold War & $-0.679^{* * *}$ & $(0.169)$ & -0.870 & $(0.893)$ \\
Regional democracy (\%) & $-1.464^{* * *}$ & $(0.528)$ & 1.343 & $(1.479)$ \\
Log autocracy duration & -0.00819 & $(0.0657)$ & -0.0498 & $(0.155)$ \\
Past regime breakdowns $(\#)$ & $0.0274^{* *}$ & $(0.0118)$ & & \\
\hline Uncensored & \multicolumn{5}{c}{98} \\
Observations & \multicolumn{5}{c}{-402.1} \\
Log lik. & \multicolumn{5}{c}{ Co } \\
\hline \hline
\end{tabular}

This model adds region dummies to the main Heckman probit model. Country clustered standarde rrors in parentheses. ${ }^{*} p<0.10,{ }^{* *} p<0.05,{ }^{* * *} p<0.01$. 


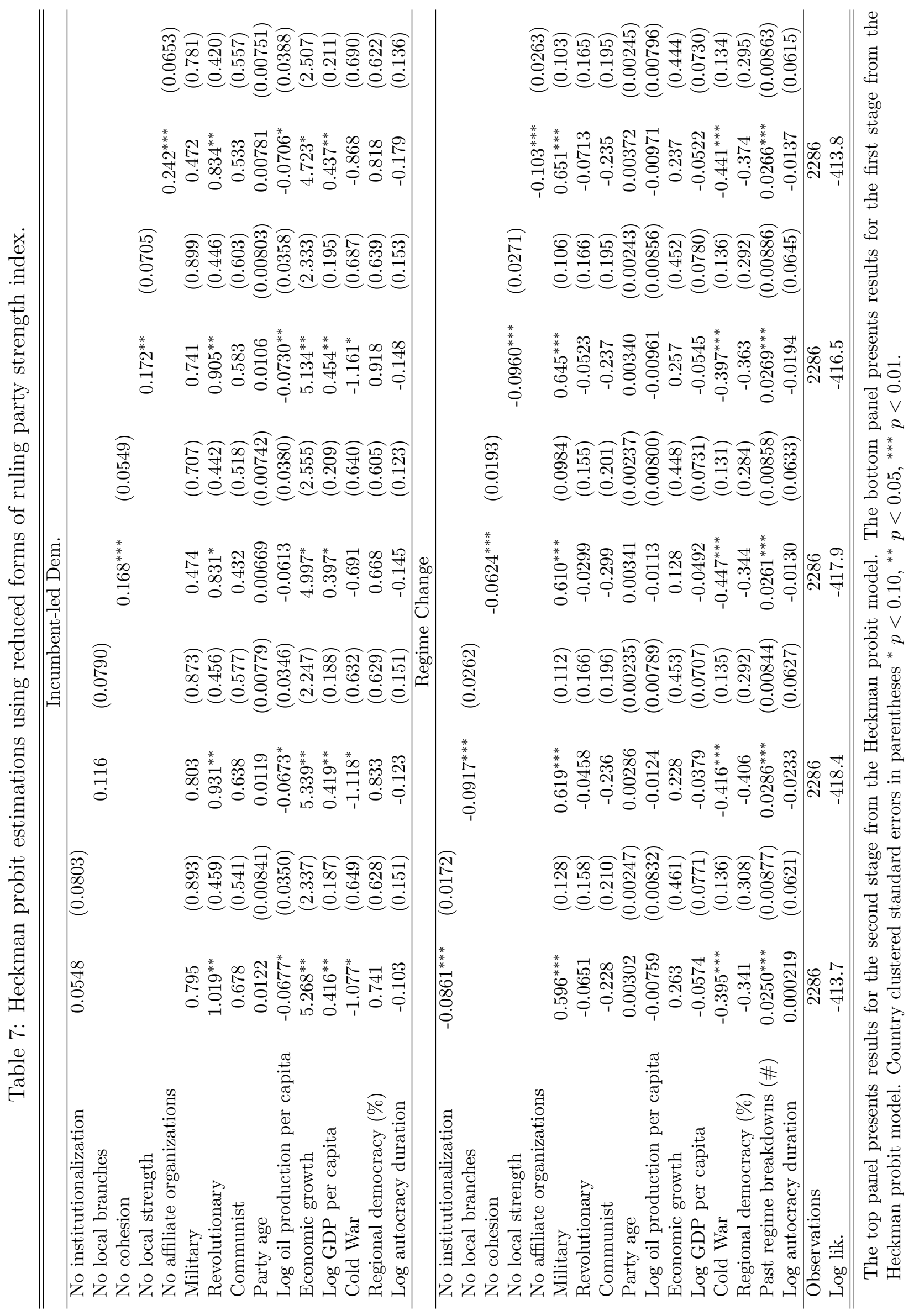

